Egyptian Poultry Science Journal

http://www.epsaegypt.com

ISSN: 1110-5623 (Print) - 2090-0570 (On line)

\title{
DETERMINING GENETIC SIMILARITY AND GENETIC DIVERSITY IN SELECTED ALEXANDRIA CHICKENS USING RAPD TECHNIQUE
}

\author{
Lamiaa .M. Radwan ${ }^{1}$, Amira E. El-Dlebshany ${ }^{2}$ and M.Y.Mahrous ${ }^{1}$ \\ ${ }^{1}$ Poul. Prod. Dep., Fac. of Agric., Ain Shams Univ., Cairo,Egypt. \\ ${ }^{2}$ Poul. Prod. Dep., Fac. of Agric., Alexandria Univ., Alexandria, Egypt.
}

\begin{abstract}
The Alexandria chicken considered as one of our Egyptian local strain. A lot of attempts were done to improve productive traits. A control line (or a base line) and another selected one are derived from this local strain. The selected line subjected to a long term selection program lasted for 16 generations from 1995 to 2011 in order to improve some egg production traits and also to reach earlier sexual maturity. This long term selection program expected to reduce most of the variations in this closed population which normally reflected on the response of selection. So, the main target was to estimate the genetic similarities by calculating the genetic improvement occurred during different generations. RAPD analysis technique used to estimate the degree of diversity and stability for this selected line. The mean average percentage differences (MAPD), genetic similarity, genetic distance based on band frequencies or based on band sharing which had been estimated for Alexandria selected and control lines. The mean average percentage difference (MAPD) into Alexandria selected and control lines recorded 0.415 and 0.667 respectively. While, genetic similarity had recorded into selected line (0.635) and into control line (0.351). The genetic distance had been calculated by two methods, the first method calculated the genetic distance on the basis of band frequency recorded 0.46 . This result explained the genetic identity index of selected and control Alexandria lines. While the second method calculated the genetic distance on the basis of band sharing recorded 0.41 . The phylogenetic relationships within 12 samples randomly taken from Alexandria selected line cleared that the degree of similarity reached $80 \%$ within line from primer 1 , $70 \%$ from primer $2 ; 65 \%$ from primer $3,50 \%$ from primer $4 ; 55 \%$ from primer 5 and $60 \%$ from primer 6 . While; this similarity when calculated within samples into line each primers recorded approximately \%63. The results of this present research concluded that, the Alexandria selected line did not consume some of the variability present in this studied population and did not yet reach genetic stability. So, it can to continue the selection program.
\end{abstract}

Key Words: RAPD-PCR, polymorphism, selection.

Corresponding author: lamia_radwan@agr.asu.edu.eg \& amiraeldlebshany@yahoo.com 


\section{INTRODUCTION}

The Egyptian local strains have some useful genetic attributes such as adaptability to our local environment, besides its resistance to some diseases. These attributes can be harnessed in a cross breeding program, especially for the development of meat and egg type chickens (Nwosu, 1987; Nwosu et al., 1985). Local strains in developing countries are still out of competition with commercial ones which benefit from the technology advantages and economic of scale (Hoffmann, 2005). We are in a great need to establish breeding programs to improve the productive performance of our local strains which distinguished with better meat quality, resistance to some diseases and its better adaptation to our local environmental conditions. Most of our developed local strains originated from cross breeding programs (Kosba and Abd El-Halim, 2008). So, crossbreeding can be used as an effective tool that allows manipulating of genetic variation to change the productive performance of these local strains in a fashion that attempts to optimize the desired phenotype and also to obtain crosses enjoyed with improved fitness and fertility traits (Willham and Pollak, 1985; Hanafi and Iraqi, 2001; Mekky et al., 2008 and Nimbkar, et al., 2008). A lot of researches do their best to develop this selected line (Kosba, 1966). They estimated the heritability $\left(h^{2}\right)$ of age sexual maturity and selection response (R) for the selected line during different generation; $h^{2}$ estimated 0.28 and $\mathrm{R}$ was 13.8(Ghanem, 1995); $\mathrm{h}^{2}$ estimated 0.03, 0.06, 0.05 and $\mathrm{R}$ was -3.9 (Abd El-Halim 1999); $\mathrm{h}^{2}$ estimated 0.28 and $\mathrm{R}$ was -5.6 (El-Tahawy 2000); $\mathrm{h}^{2}$ estimated 0.32 (Ghanem 2003); $\mathrm{h}^{2}$ estimated 0.34 and $\mathrm{R}$ was +6.3 (El-Delbshany 2004) and $h^{2}$ estimated 0.26 and $\mathrm{R}$ was -4.2 (Khalil 2010).

The aim of this present study was to estimate the genetic similarities by calculating the genetic improvement occurred during different generations by using RAPD analysis technique trying to answer the question does the selected line reaches Plateau stage or not.

\section{MATERIAL AND METHODS}

\section{Experimental stocks:}

The Alexandria line had long term selection program lasted for 16 generation. The criteria of selection had earlier age at sexual maturity (Zatter, 1994 and Ghanem, 1995). The comparison held between this selected line and another one taken randomly from the base population.

The field work was done at the Poultry Research Center, Faculty of Agriculture, Alexandria University, while, the lab work, including RAPD analysis was fulfilled at the Dept. of Poultry Production, Faculty of Agriculture, Ain Shams University.

\section{DNA preparation:}

A sample of 1-2 $\mathrm{ml}$ blood was taken via the brachial vein at $16 \mathrm{wk}$ of age from each of 16 samples (6 samples from each line) randomly chosen from each of the fore lines. Each blood sample was mixed with $50 \mu \mathrm{l}$ of $0.5 \mathrm{M}$ EDTA, and frozen at $70^{\circ} \mathrm{C}$ until analyzed. The DNA was isolated from blood using AXYGEN kit Axyprep TM). Isolated genomic DNA was purified using spin column. Both products from Axygen Scientific, inc. USA Cat. No. APMN-BL-GDNA-50.

\section{PCR cycling parameter:}

Amplification was performed in a thermo cycler (LongGene - MG96G/china) with the following temperature profiles: initial denaturation $95{ }^{\circ} \mathrm{C}$ for $4 \mathrm{~min}, 37$ cycles (denaturatiom $95^{\circ} \mathrm{C} 1 \mathrm{~min} /$ annealing temp. depending on the primer $\left({ }^{\circ} \mathrm{C}\right) 1$ min/extension $72^{\circ} \mathrm{C} \quad 1 \mathrm{~min}$ and Final extention $72^{\circ} \mathrm{C} 5 \mathrm{~min}$. The reaction was hold at $4^{\circ} \mathrm{C}$. 


\section{Amplified DNA Analysis:}

The PCR products $(15 \mu \mathrm{l})$ were resolved by electrophoresis by using $1.5 \%$ agarose gel (horizontal) or in $10 \% \mathrm{PAG}$ (vertical) in $1 \mathrm{X}$ Tris-Borate-EDTA (TBE) buffer at $70 \mathrm{~V}$ for $90 \mathrm{~min}$. and $100 \mathrm{bp}$ DNA ladder (Larova $\mathrm{GmbH} / \mathrm{Germany}$ ) were used as DNA size markers. Gels were stained with ethidium bromide (EtBr) $10 \mathrm{ug} / \mathrm{ml}$ for $15 \mathrm{~min}$ followed by water washing for 15 min. Gels were visualized with UV light and and photographed by a Sony digital camera.

\section{Genetic improvement and data analysis:}

The improvement in the last fourth generation calculated by this equation (Zein El-Dein 1977)
Where,

$$
=\partial \mathrm{p}_{13} / \partial \mathrm{p}_{16} * \mathrm{~h}^{2}{ }_{13} / \mathrm{h}^{2}{ }_{16}
$$

$\partial \mathrm{p}_{13}=$ square root of the total phenotypic variance of $13^{\text {th }}$ generation,

$\partial p_{16}=$ square root of the total phenotypic variance of $16^{\text {th }}$ generation,

$\mathrm{h}^{2}{ }_{13}=$ heritability estimated of $13^{\text {th }}$ generation,

$\mathrm{h}^{2}{ }_{16}=$ heritability estimate of $16^{\text {th }}$ generation.

Phylogenetic tree was constructed on the basis of similarity matrix obtained with neighbor joining (NJ) method using Jaccard formula $d_{j k}=M /(M+N)$. The relationships between genotypes were displayed as dendrogram using the NTSYSpc 2.01 software package (Rohlf, 1998).

As for, percent polymorphism it was calculated by using the formula,

Percent polymorphism $=\quad \frac{\text { Total number of polymorphic bands }}{\text { Total number of bands }} \times 100$

Genetic similarity among chicken groups was estimated by scoring the presence and absence of bands produced by primers. The presence (1) or absence (0) of a band of a particular molecular weight were scored as two alleles at a single locus.
Molecular size of SSR and RAPD PCR bands separated on gels were calculated by analyzing gel images with GelAnalyzer software package version 2010a (free wear).

Table (1): the name and Sequence of primer

\begin{tabular}{|l|l|}
\hline \multicolumn{1}{|c|}{ Primer name } & \multicolumn{1}{|c|}{ Primer sequence } \\
\hline OPA-01 & $5^{`}$ CAGGCCCTTC $3^{\backslash}$ \\
OPB-01 & $5^{`}$ GTTTCGCTCC $3^{\backslash}$ \\
OPB-03 & $5^{`}$ CATCCCCCTG 3 \\
OPB-14 & $5^{`}$ TCCGCTCTGG $3^{\backslash}$ \\
OPG-01 & $5^{\backslash}$ CTACGGAGGA $3^{\backslash}$ \\
OPZ-01 & $5^{`}$ TCTGTGCCAC $3^{\backslash}$ \\
\hline
\end{tabular}




\section{Mean Average Percentage Difference (MAPD):}

Mean Average Percentage Difference (MAPD) was calculated as a measure of inter lines genetic divergence and was expressed in the form of mean described by Gwakisa et al. (1994) by using the formula: Percentage Difference (PD):

$\mathrm{PD}=(\mathrm{Nab} / \mathrm{Na}+\mathrm{Nb}) \times 100$

Average Percentage Difference (APD): APD $=1 / C$ G Pdi.

Mean Average Percentage Difference (MAPD): $\mathrm{MAPD}=1 / \mathrm{R}$ G Pdi

Where: $\mathrm{Nab}=$ The number of fragments that differ., $\mathrm{Na}$ and $\mathrm{Nb}=$ The number of fragments in pool $\mathrm{a}$ and $\mathrm{b} ., \mathrm{C}=$ The number of inter-lines pair-wise comparisons.

$\mathrm{R}=$ The number of random primers used.

Genetic similarity based on band frequency: The within lines genetic similarity $\left(\mathrm{WF}_{\mathrm{i}}\right)$ was estimated using the equation given by Singh and Sharma and Dhama (2007).

$\mathrm{WF}_{\mathrm{ij}}=1 / \mathrm{N} \sum \mathrm{V}_{\mathrm{i}}$

Where: $\mathrm{Vi}=$ The proportion of individuals possessing the $\mathrm{I}$ th band across all the individuals., $\mathrm{N}=$ The total number of bands amplified.

The genetic similarity between two lines known as genetic identity index ( $\mathrm{Yu}$ and Pauls 1993; Zhang et al., 1995) was obtained from the following formula;

$$
\mathrm{BF}_{\mathrm{ij}}=\sum_{\left.\left(\mathrm{V}_{\mathrm{i}}{ }^{(2)}\right)^{2}\right]}^{1 / \mathrm{N}}\left[2\left(\mathrm{~V}_{\mathrm{i}}{ }^{(1)} \mathrm{V}_{\mathrm{i}}^{(2)}\right) / \mathrm{V}_{\mathrm{i}}{ }^{(1)}\right)^{2}+
$$

Where: $\mathrm{V}_{\mathrm{i}}^{(1)}$ and $\mathrm{V}_{\mathrm{i}}^{(2)}=$ The frequency of occurrence of the $i$ th band in Line 1 and 2, respectively., $\mathrm{N}=$ The total number of bands scored.

\section{Genetic distance based on band frequency:}

An index of genetic distance Dij between two lines was calculated by the following equation.
Dij = - ln (Bfij). Where: $($ BFij) $=$ The genetic identity index of two lines.

\section{Genetic distance based on band sharing:}

The genetic distance between the lines were also calculated based on band sharing between the pooled samples RAPD profiles. The genetic distance (Dab) between the selected line (A) and control line (B) was calculated as: $\mathrm{Dab}=1 / \mathrm{N} \mathrm{G1}$ $\{\mathrm{Nab} /(\mathrm{Na}+\mathrm{N}$ b $-\mathrm{Nab})\}$

where: $\mathrm{Nab}=$ No. of common bands between $\mathrm{A}$ and $\mathrm{B}$., $\mathrm{Na}=\mathrm{No}$. of bands in $\mathrm{A}$. $\mathrm{N} \mathrm{b}=$ No. of bands in B., $\mathrm{N}=$ No. of primers used.

\section{STATISTICAL ANALYSIS}

All scored bands of DND data was firstly corrected to estimate each allele size according to its number of repeats for each marker GelAnalyzer software package was adopted for this purpose. Then, a spread sheet program (Microsoft Excel) was used to arrange the included data for each line regarding each locus. All possible extracted population figures were carried out employing a GENEPOP software package after data conversion using CON.

\section{RESULTS AND DISCUSSION}

A long term selection program lasted from 16 generations in order to reach early age sexual maturity and also to improve some egg production traits, was practice in a selected line proved from Alexandria strain. Accordingly different genetic responses and genetic improvements were attended from generation to another, specially in the last four generation (Table 2). The attend results indicated that we are still in need to continue these selection program for another several generations to attain more and more selection responses in order to improve these studies traits. 
Table (2): Heritability estimates and cumulative selection response of age at sexual maturity for Alexandria selected egg line.

\begin{tabular}{|l|l|l|}
\hline \multicolumn{1}{|c|}{ Author } & \multicolumn{1}{|c|}{ Hertability } & \multicolumn{1}{c|}{ Selection Response (days) } \\
\hline Ghanem, 1995 & 0.28 & -13.8 \\
Abd El-Halim, 1999 & $0.03,0.06,0.05$ & -3.9 \\
El-Tahawy, 2000 & 0.28 & -5.6 \\
Ghanem, 2003 & 0.32 & - \\
El-Dlebshany, 2004 & 0.34 & +6.3 \\
Khalil, 2010 & 0.26 & -4.2 \\
\hline
\end{tabular}

Genetic improvement in the last fourth generation $=\partial \mathrm{p}_{13} / \partial \mathrm{p}_{16} * \mathrm{~h}^{2}{ }_{13} / \mathrm{h}^{2}{ }_{16}=438 / 317 *$ $0.34 / 0.26=1.81$

Table 3 showed the mean average percentage difference (MAPD) into the selected line and also into the control. The corresponding estimates were $0.415,0.667$ respectively. Moreover, genetic similarity which recorded for the selected line was 0.635 , while it was 0.351 only in the control one. . Chatterjee et al., 2006 and 2007 estimated the MAPD between different inbred (HS and FS) the non inbred White Leghorn (WL) population. There results demonstrated the MAPD was lower for the non inbred populations when compared with those of pure ones.

The genetic distance had been calculated by two methods, the first calculated genetic distance one the based of band frequency. Accordingly, the genetic distance recorded 0.46 , this results indicates the genetic identity of these two line (the selected line and the control one ). The second methods calculated the genetic distance on the base on the base of band sharing. According to this last methods, the genetic distance recorded 0.41 .

Table (3): Mean average percentage difference, genetic similarity and genetic distance from selected and control lines.

\begin{tabular}{|l|l|l|}
\hline \multicolumn{1}{|c|}{ Parameters } & \multicolumn{2}{c|}{ Lines } \\
\cline { 2 - 3 } & \multicolumn{1}{c|}{ Selected } & \multicolumn{1}{c|}{ Control } \\
\hline Mean Average Percentage Difference & 0.415 & 0.667 \\
Genetic similarity & 0.635 & 0.351 \\
Genetic distance based on band frequency & 0.46 & \\
Genetic distance based on band sharing & 0.41 & \\
\hline
\end{tabular}




\section{Phylogenetic relation:}

Cluster analysis of the RAPD pattern (Fig. 1) of the selected line show difference and similarity between samples of selected line. Within-population genetic variation may reflect the different sources of origin of the lines and their subsequent propagation. Using Statistica software, Unweighted Pair Group Average Method (UPGAM) of analysis was performed based on RAPD data, and a dendrogram was constructed to show the phylogenetic relationships within 12 samples randomly chosen from Alexandria selected lines of consideration (Figure 2). The degree of similarity reach $80 \%$ within line from primer $1,70 \%$ from primer $2 ; 65 \%$ from primer $3,50 \%$ from primer $4 ; 55 \%$ from primer 5 and $60 \%$ from primer 6 . While; when calculating similarity within samples into line, each primer reaches approximately \%63. The Alexandria selected line had originated from different sources (Alexandria, Norfa and Matrouh.), were crossed and subjected to similar selection regimes but their response to selection could vary Hence, some diversity between them is expected. due to their differential reproductive and productive potentials. The cluster analysis in other chicken populations was also observed by earlier workers (Chatterjee et al., 2006; Ahlawat et al., 2004).

Khosravinia et.al, 2005 studied genetic distance and genetic similarity within lines HC, BPB2, CPB2, PB2 and UM1 lines used randomly amplified polymorphic DNA techniques (RAPD techniques) and reached the same observation and conclusion. Within-line genetic similarity/distance estimates derived from band sharing from Alexandria selected lines concerned are presented in fig 1 and 2 . The genetic similarity values based on band frequency were utterly of same trend as those derived from band sharing.

The control line used this experiment due to vindicate the degree of differentiations of selected lines. RAPD Markers have many important and useful applications in poultry improvement. Some of the many applications will be briefly discussed: Establishing genetic relationships; predicting heterosis; Genomic selection; and Marker Assisted Selection (MAS). A more comprehensive discussion of some of these areas can be found in Muir (1994; 1996, 1997), Francesch et al., (1997), and Ahlawat et al., (2004).

The selected line not reach Plateau stage and the additive variance not consumed due to the selection programs which avoided danger inbreeding. In the present study the focus was on determining the genetic similarity and variability between the selected line and control line, since the lines belong to the same breed, characterization at the molecular level was necessary to unravel the genetic variation between them as a result of recurrent inbreeding.

\section{CONCLUSION}

The Alexandria line which subjected to a long term selection program lasted for 16 generations in order to reach earlier sexual maturity had not yet reaches stability stage.

\section{ACKNOWLEDGMENT}

Dr. Medhat EL-DENARY Assistant professor in Genetics Department, Faculty of Agriculture, Tanta University, had supply analysis Phylogenetic relation. 


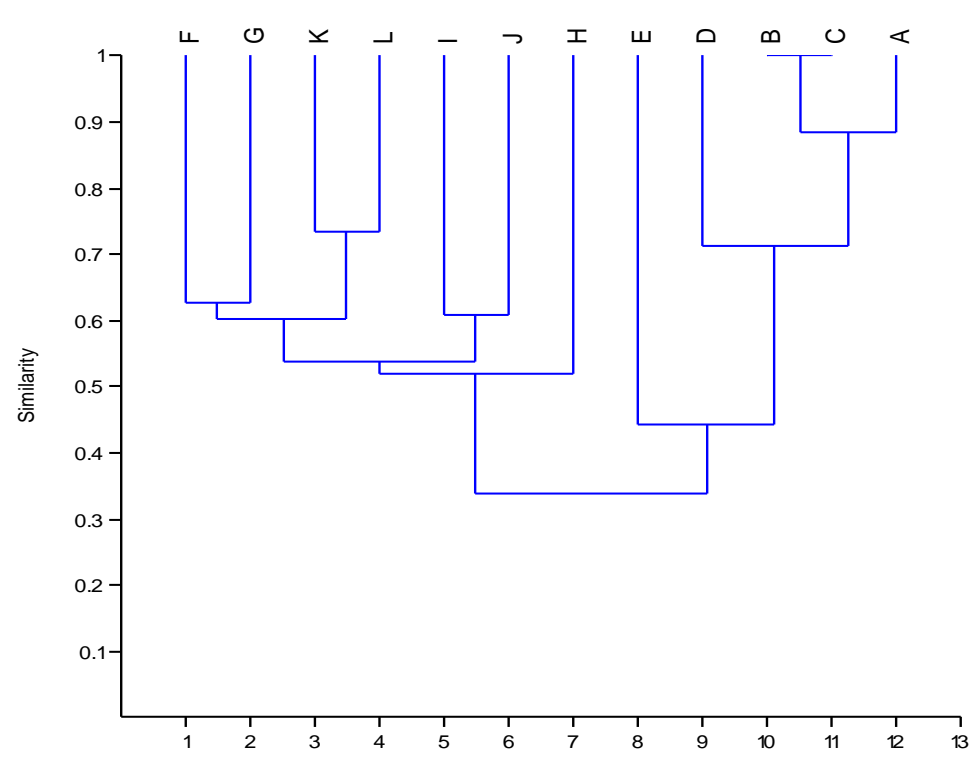

Fig. (1): dendrogram genetic similarity into Alesendria selected line according to RAPD analysis

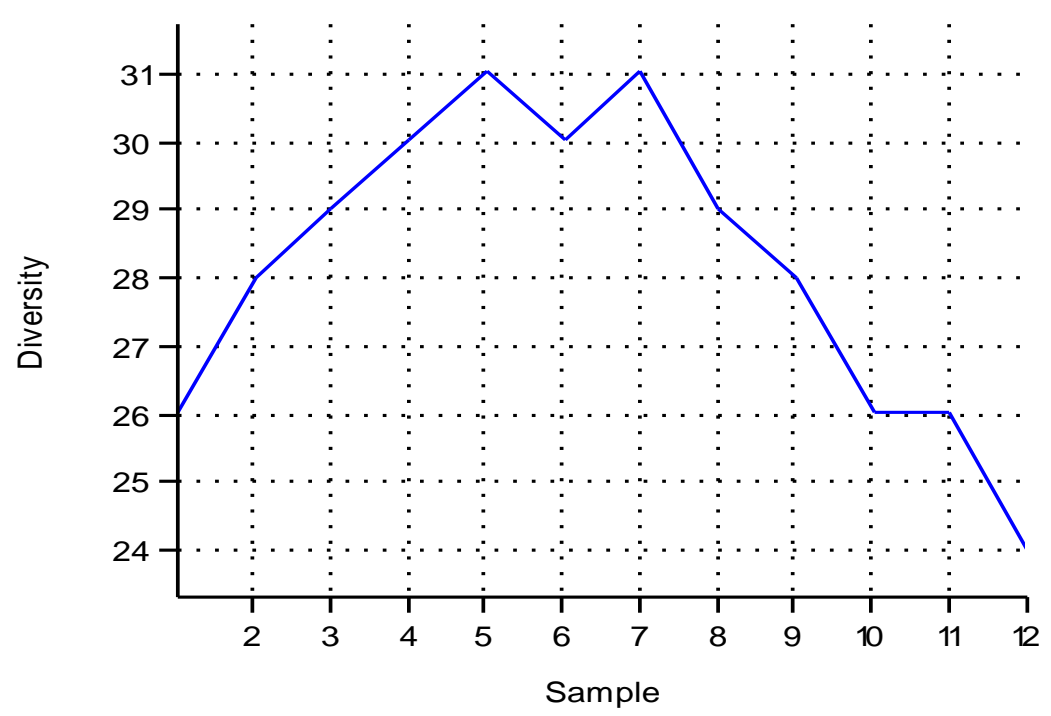

Fig. (2): Cluster analyses of genetic diversity within Alexandria selected line according to RAPD analysis. 


\section{REFERENCES}

Abd El-Halim, H.A., (1999). Selection and genetic analysis of some meat and egg production traits in local chickens. M.Sc. Thesis, Fac. of Agric., Alex. Univ., Egypt.

Ahlawat, S.P.S., Sunder J., Kundu A., Chatterjee R.N., Rai R.B., Kumar B., Senani S., Saha S.K. and Yadav S.P. (2004). Use of RAPDPCR for genetic analysis of Nicobari fowl of Andamans. Br. Poult. Sci., 45: 1-7.

Chatterjee, R.N., Sharma R.P., Reddy B.L.N., Niranjan M., Shivaprasad A. and Mishra S.K. (2007). Genetic Analysis of Highly Inbred Chicken Using RAPD-PCR and immunocompetence. International Journal of Poultry Science 6 (12): 967-972.

Chatterjee, R.N., Sharma R.P., Mishra S.K., Niranjan $M$. and Reddy B.L.N. (2006). Genetic analysis of White Leghorn pure lines using RAPD-PCR and immune competence. Indian J. Poult. Sci., (Submitted).

EI-Dlebshany E. A. (2004). Genetic and cytogenetic studies of inbreeding in local chickens. Ph.D. Thesis, Faculty of Agriculture, Alex. University, Egypt.

El-Tahawy W.S. (2000). Genetically improvement of some productive and reproductive traits in local chicken. M. Sc. Thesis, Faculty of Agriculture, Alex. University, Egypt.

Francesch A. Estany J., Alfonso L. and Iglesias M. (1997). Genetic parameters for egg number, egg weight, egg shell colour in three Catalan poultry breeds. Poultry Science. 76: 1627-1631.

Ghanem H. H. (1995). Selection for age at sexual maturity in Alexandria chickens. M.Sc. Thesis, Faculty of Agriculture, Alex. University, Egypt.

Ghanem H. H. (2003). Selection for low yolk cholesterol and its correlated response on some economic traits in local laying hens strain. Ph. D. Thesis, Faculty of Agriculture, Alex. University, Egypt.

Gwakisa P.S., Kemp S.J. and Teale A.J. (1994). Characterization of Zebu cattle in Tanzania using random amplified polymorphic DNA markers. Anim. Genet., 25: 89-94.

Hanafi M. S. and Iraqi M. M. (2001). Evaluation of purebreds, heterosis, combining abilities, maternal and sex- linked effects for some productive and reproductive traits in chickens. 2 nd international Conference on Animal Production and Health in Semi - Arid Areas, 4-6 September, El-Arish-NorthSinai, Egypt, 545 - 555.

Hoffmann I. (2005). Research and investment in poultry genetic resource - challenges and options for sustainable use. World' s Poult. Sci. J., 61 (10): 57-70.

Khalil M.H. M. A. (2010). Selection and correlated response of some performance traits before and after random mating in Alexandria chickens. Ph. D. Thesis, Faculty of Agriculture, Alex. University, Egypt.

Khosravinia H., Murthy H. N. N., Ramesha K. P. and Govindaiah M. G. (2005). Multi trait selection with restriction for cutup carcass value in broiler chicken: Genetic relatedness of lines involved based on randomly amplified polymorphic DNA. Asian-Aust. J. Anim. Sci. 2005. Vol 18: 1535-1541.

Kosba, M.A. (1966). Analysis of an experiment on selection for economic traits in chickens. M. Sc. 
Thesis, Fac. of Agric., Alex. Univ., Egypt.

Kosba, M.A. and H.A.H.Abd El-Halim (2008). Evaluation of the egyption local strains of chikns. Egypt Poult. Sci. Vol (28) : (1239-1251).

Mekky S.S., Galal A., Zaky H.I. and Zein-El-Dein A. (2008). Diallel crossing analysis for body weight and egg production traits of two native Egyptian and two exotic chicken breeds. Int. J. Poult. Sci., 7: 64-71.

Muir W. M. (1994). Poultry improvement: Integration of present and new genetic approaches for layers. Proc. $5^{\text {th }}$ World Congress of Genetics Applied to Livestock Breed- ing, Guelph, Canada. 20:5-12

Muir W. M. (1996). Group selection for adaptation to multiple-hen cages: selection program and direct response. Poult. Sci. 75: 447-458.

Muir W.M. (1997) .Genetic SelectionStrategies for the future. Poultry Science 76:1066-1070.

Nimbkar C., Gibson J., Okeyo M., Boettene $P$. and Soelknor J. (2008). Sustainable use and genetic Improvement. Animal Genetic Resources Information AGRI, 2008, 42: $49-69$.

Nwosu C.C. (1987). Is the local chicken essential or non essential? Invited paper, Agric. Ext. and Res. Liaison Service, A.B.U. Zaria. Dec. 1987, pp: 1-16.

Nwosu C.C., Gowen F.A., Obioha F.C., Akpan I.A. and Onuora G.I. (1985). Biometrical study of the conformation of the native chicken. Nig. Journal of Animal production, 12: $141-146$.
Rohlf F.J. (1998). NTSYSpc Numerical Taxonomy and Multivariate Analysis System Version 2.0 User Guide. Applied Biostatistics Inc., Setauket, New York. 1998, 37 pp.

Sharma D. and Dhama K. (2007). Genetic polymorphism between guinea fowl lines with high and low antibody response to sheep red blood cells using randomly amplified polymorphic DNA (RAPD) markers. Indian Journal of Comparative Microbiology, Immunology and Infectious Diseases 28(1 - 2), unpaginated.

Willham I. and Pollak A. (1985). A transaction cost approach to families and household 15: journal economic literature 581- 608.

Yu, K. and Pauls K.P. (1993). Rapid estimation of genetic relatedness among heterogeneous population of alfalfa by random amplification of bulked genomic DNA samples. Theoret. Applied Genet., 86: 788794.

Zatter O.M.M. (1994). Genetic studies in poultry. Effect of cross breeding between new local strains of chicken on some productive traits. M. Sc. Thesis, Fac. of Agric., Alex. Univ., Egypt.

Zein El-Dein A. (1977). Effect of some environmental conditions on heritability and some other geneticparameters in chickens. Ph.D. Thesis, Faculty of Agriculture, Ain shams. University, Egypt.

Zhang X., Mcdaniel C.R., Giambome J.R. (1995). Random amplified polymorphic DNA comparisons among broiler lines selected for incidence of tibia dyschondroplasia. Poult Sci. 74: 1253- 1258. 


\section{تقدير التشابه الوراثى والتباين الوراثى فى دجاج الاسكندرية المنتخب باستخدام تقتية RAPD المبلية

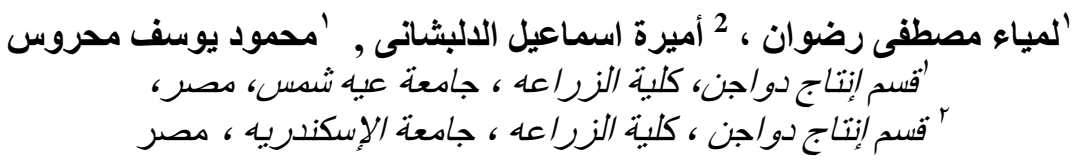

يعتبر دجاج اسكندرية من إحدى السلالات المحلية المحسنة والذى اجرى الإلى علية كثير من الأبحاث لتحسين

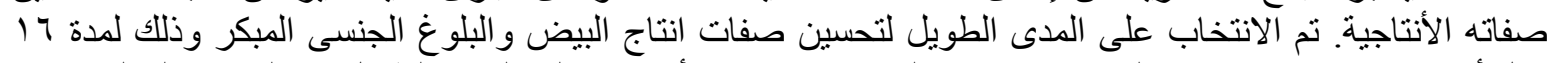

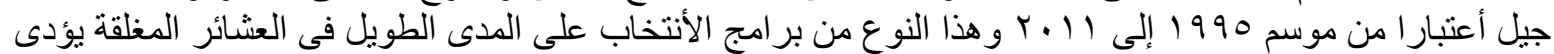
إلى تقليل الأختلافات وينعكس ذلك على الإنى الأستجابة للإنتخاب.

الهدف الأساسى من هذه الدراسة تقدير التشابه الور اثتى وذلك بحساب التحسين الوابل الور انتى خلال الأجيال المختلفة.

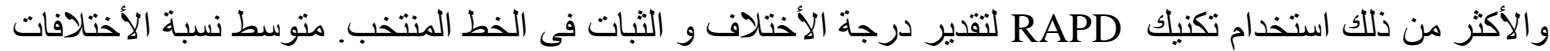

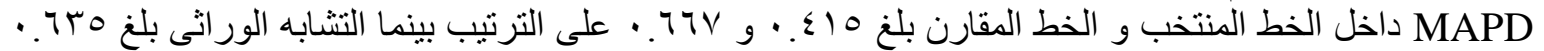

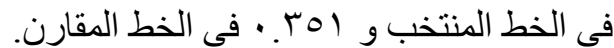

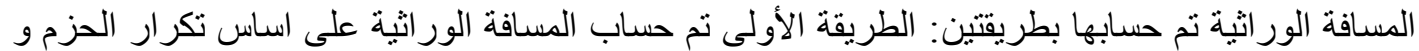

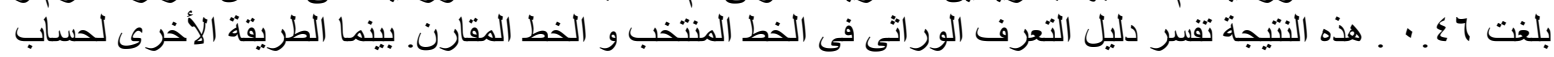

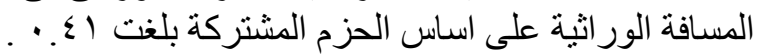

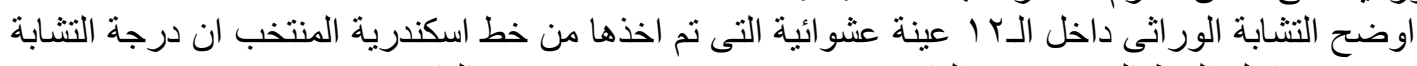

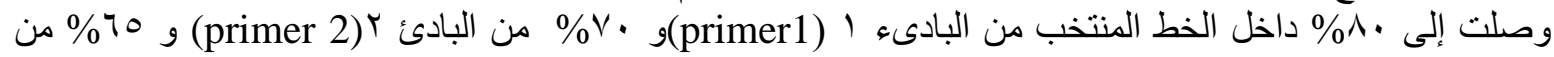

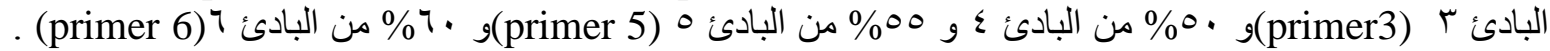

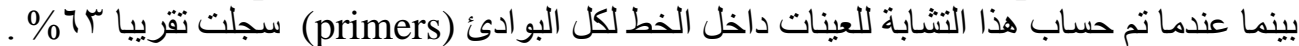

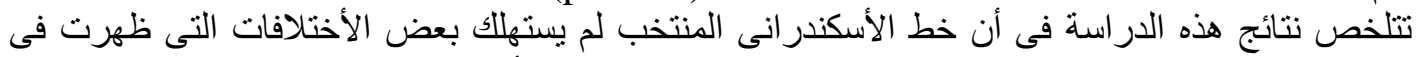
العثيرة المدروسة و لم تصل بعد للثبات الور اثى لذللك يمكن ان يستمر برنامج الأنتخاب. 